Our Nature (2012) 10: 1-7

\title{
Estimating Population Density of Himalayan Rangeland Weed Senecio chrysamthemoides DC.
}

\author{
Dil Kumar Limbu ${ }^{1 *}$ Ram Prasad Khatiwada ${ }^{2}$ and Madan Koirala ${ }^{3}$ \\ ${ }^{1}$ Central Campus of Technology, Dharan, T.U., Nepal \\ ${ }^{2}$ Central Department of Statistics, Kirtipur, T.U., Nepal \\ ${ }^{3}$ Central Department of Environmental Science, Kirtipur, T.U., Nepal \\ *E-mail: dilklimbu@yahoo.com
}

\begin{abstract}
Unpalatable and unwanted native or invasive plants that have adverse impact on the forage in the grazing area are rangeland weed. Climate change, introduction of new species, disturbance and fragmentation of land are causative factors for spreading native or invasive weed infestation on rangelands. Senecio chrysanthemoides is a serious obnoxious weed on Himalayan rangeland area. It is densely populated on plain and left places of shed constructed area consequent rangeland degraded, displacing desirable species, degrading systems, decreasing productivity and increase management costs. To arrest infestation of weed, mechanical control measure was followed but unplanned mechanical control measure was inadequate. Up-rooting weed earlier flowering was more effective than other life form of weed.
\end{abstract}

Key words: Control, Himalaya, population, rangeland, weed

\section{Introduction}

Plants which are unpalatable, unwanted and worthless native or invasive species that have adverse impact on the forage species in the grazing area are rangeland weed. Weed plants are mostly invasive species. These are nuisance in grazing land. Rangeland weed are poisonous and economically adverse. Invasive weed plant species negatively impact rangelands throughout the world by displacing desirable species, altering ecological processes, reducing wildlife habitat, degrading systems, decreasing productivity and increase management costs associated with herbicide application and pasture renovation (DiTomaso, 2000; Masters and Sheley, 2001). Many weeds are hosts of plant disease organisms. Climate change, introduction of new species, disturbance and fragmentation of land are causative factors for spreading native weed or invasive weed infestation on rangelands. Research in weed population dynamics is very important for the design of effective and environmentally friendly weed control strategies (Navas, 1991; Cousens and Mortimer, 1995; Liebman et al., 2001). Several works have studied the dynamics of weed populations and have tried to model those (Holst et al., 2007). Weed populations can show significant genetic differentiation between fields (Cavers, 1985), but will mostly occur as mixtures of genotypes within fields. Within a field, their distribution may be highly non-uniform (Rew et al., 1996), and their abundance may fluctuate markedly from year to year (Chancellor, 1985).

In Himalayan rangeland, the spread and dominance of weeds plant species has been identified as a serious threat to 
Dil Kumar Limbu, Ram Prasad Khatiwada and Madan Koirala / Our Nature (2012) 10: 1-7

rangeland biodiversity and ecosystem functioning. Intense grazing of grasslands often results in palatable species being replaced by less palatable species, which are often considered "less desirable or even worthless plants" (Vallentine, 1990). Rangeland weed identification and management on Himalayan rangeland has not addressed in Nepal (Limbu et al., 2012). We do not have the actual report of rangeland weed even checklist. 166 species of invasive weed (Tiwari et al., 2005) and 364 crop weed (Rajbhandari and Joshi, 1998) of temperate and tropical zone and 8 highly noxious high altitude rangeland weeds (Limbu et al., 2012) have been reported from Nepal.

Senecio chrysanthemoides is a serious invader on Himalayan rangeland area of Eastern Nepal. Morphologically, it is 2-4 feet tall compositae herb, lower leaves lyrate-pinnatifid with an auricled petiole, upper leaves sessile, bipinnatifid, base amplexicaul, surface white pubscent, numerous yellow flower head, flower head with 10-12 spreading ray florets, Ray floret few; disc florets many with shortly 5 fid tubular corollas. Achenes smooth. It is annual herb that becomes perennial under defoliation, flowering on AugustSeptember, locally called 'Toriphule'. Usually, it occurs at 2400 to $3600 \mathrm{msl}$ in Himalayan open rangeland area. It grows mostly fertile, plain land and heavily colonies on leaving places of temporary cows' sheds.

Over the last decades herdsmen of the Himalaya rangeland have been facing great infestation of $S$. chrysanthemoides on their pasturelands. Infestation area and population of the weed has been escalating since its introduction. It is unpalatable, broad leaves and fast growing invasive species. With having broad leaves, it sheds over grasses; other forbs plant could not compete for growing and nutrition. On other hand, it produces large number of seed at a time and dominates over the forage plant consequent degrade rangeland quality.

The objective of this paper is to estimate the population density of Senecio chrysanthemoides on rangeland area of Tinjure-Milke. Ultimately, this finding could lead to control and management of $S$. chrysanthemoides, especially for better rangeland management.

\section{Materials and methods}

\section{Study area}

The research work was conducted in Tinjure - Milke Mountain ridge, political border of three districts i.e. Taplejung, Tehrathum and Sankhuwasabha, $\left(27^{\circ} 09^{\prime} 30.5^{\prime \prime}\right.$ to $27^{\circ} 22^{\prime} 15^{\prime \prime} \mathrm{N}$ and $87^{\circ} 26^{\prime} 09^{\prime \prime}$ to $\left.87^{\circ} 34^{\prime} 14^{\prime \prime} \mathrm{E}\right)$ of eastern Nepal (Fig. 1). The altitude of the study area

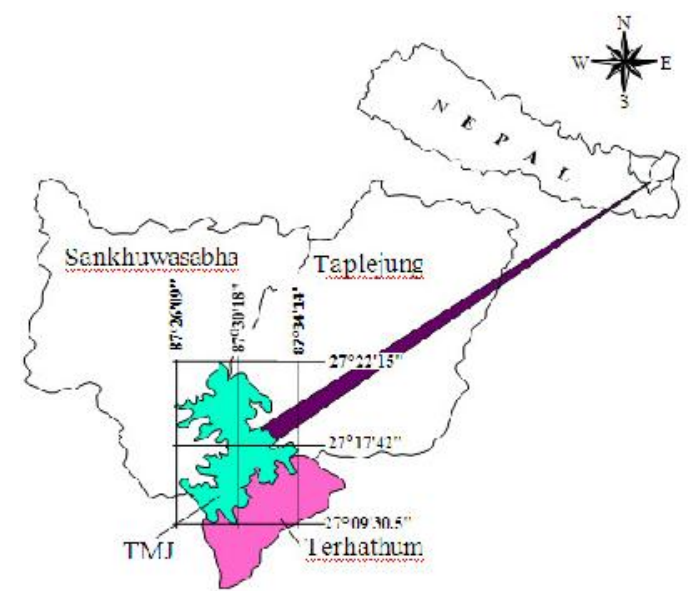

Figure 1. Map of the study area, TMJ

ranges from 2650 to $3400 \mathrm{msl}$ and far from $225 \mathrm{~km}$ east of Kathmandu. Its climatic condition is average temperature $10-15^{\circ} \mathrm{C}$ and average annual rainfall $2250 \mathrm{~mm}$. The 
area is under heavy human and livestock (yak, cattle, buffaloes, sheep and goats) pressures (Oli, 2002). It serves as habitat corridor between Makalu-Barun Conservation Area towards northwest and Kanchenjunga Conservation Area towards north-east, both of which touch the Qomolongma Biosphere Reserve in Tibet (Koirala, 2002).

The mountain ridge across TinjureMilke is the natural niches for dozens of rhododendron species. This is the capital of rhododendron of Nepal and home of 27 rhododendron species.

\section{Experimental design}

Study area was chosen Simkharka, Gupha pokhari, western aspect of Tinjure-Milke mountain ridge. We carried out observation data collection on September 2012. Landscape of the study area is diverse and left open space of cattle sheds. We interviewed 5 senior citizens, 10 senior herdsmen and 2 social activists for control measure of weed. Our questions were both open ended and close ended. We divided the study area into two broad categories a) use of the land for making temporary shed for cattle and b) slope of the land. Further, these both categories were divided into two alternative sub-categories. We classified use of the land as i) shed-constructed area (SA), where the emblems of shed construction remarked and ii) not shed-constructed area (NSA). The slope of the land was considered as i) highly sloped (HS), which bears $45^{\circ}$ or more inclination and ii) gently sloped (GS), which had less than $45^{\circ}$ inclinations. To quantify population density of Senecio chrysanthemoides, at least 38 quadrats of $2 \mathrm{~m} \times 2 \mathrm{~m}\left(4 \mathrm{~m}^{2}\right)$ size were laid down randomly from shed-constructed and not constructed area. During the preliminary survey, 17 shed-constructed areas (spots) were identified in the study area. Among which 4 spots were on highly sloped (HS) land and 13 were on gently sloped (GS) land. For comparison of the population density of the $S$. chrysanthemoids plant, 21 spots were selected from not shedconstructed area (NSA), of which 7 were from the gently sloped (GS) and 14 from the highly sloped (HS) land. Entire $S$. chrysanthemoides plants of laid down quadrat were counted and recorded. The distribution of sample is given in the $2 \times 2$ contingency table (Tab. 1). The experimental data were analysed by using software SPSS-20 (2011).

\section{Results and discussion}

At first, the significance of the sample choice is tested using $\chi^{2}$-test. The selection of sample area according to slope of the land and use of the land found to be significant, since, the computed chi-squared value $(=7.012)$ seemed significant with $\mathrm{p}$ value $(.008)<0.01$ at 1 degrees of freedom (df).

Descriptive measures like range, mean and standard deviation of the population density are computed for each sample subcategories. The estimated population density of the Senecio chrysanthemoides from all samples (spots) is 30.04 per metre square area with a standard deviation of 14.98 . The population densities for SA, NSA, HS and GS are $44.32 \pm 10.97, \quad 18.48 \pm 2.24$, $21.88 \pm 7.12,37.97 \pm 16.48$ respectively. The $95 \%$ interval estimates of the population densities of the same sample sub-categories are obtained 38.69-49.96, 17.46-19.50, 18.33-25.42 and 29.68-45.10 per metre square area respectively (Tab. 2). The Box and whisker plot shows the distribution of population densities in the different 
Dil Kumar Limbu, Ram Prasad Khatiwada and Madan Koirala / Our Nature (2012) 10: 1-7

categories of the sample. The distribution of the population densities in highly sloped shed-constructed area and not shedconstructed area are symmetrical in nature. An outlier value of the population density is observed in the distribution of population density in gently sloped not shedconstructed area (Fig. 2).

The population density of the Senecio plant is highest for the shed-constructed area among all categories. For the gently sloped shed-constructed area, the population density (at $95 \%$ confidence interval) is estimated 40.9-53.9 plants per meter square area. The distribution is observed less dense on the highly sloped not shed-constructed area, the $95 \%$ interval estimate of which is 17.16-19.48 plants per metre square area (Tab. 3). The t-test is employed for testing the equality of means of the population densities (Senecio) in between the subcategories SA and NSA, and HS and GS. Assuming equal variances, the independent sample t-test for testing equality of the means between NSA and SA reveals $t=-$ 10.568 for 36df. The population densities between shed-constructed area (SA) and not shed-constructed area (NSA) is observed significantly different, since p-value $(=0.002)<0.1$. Similarly, under the assumption of equal variances, the t-value on testing equality of the means between highly sloped (HS) and gently sloped (GS) land is obtained as -3.692 . This confirms that the population densities over highly sloped and gently sloped lands are also significantly different, since p-value (= $0.001)<0.1$.

Population density of Senecio chrysanthemoides is escalating day by day since its infestation due to climate change and overgrazing of rangeland. Weed population density distribution is influenced by biotic and abiotic environment, landscape, rainfall, grazing intensity, rangeland management, fertilizer and herbicides treatment. Weed populations are dynamic in time, both within and between seasons, and in space, both within and between fields. Weed models should therefore ideally simulate the population dynamics along both these axes (Mortimer and Putwain, 1984; Van Groenendael, 1988; Colbach and Debaeke, 1998). Intra- and interspecific competitions are key processes in weed population dynamics (Blom, 1988) and ecophysiological models have been suggested as the most appropriate tool for exploring these interactions (Kropff et al., 1996).

Abandoned places after cattle's shed were very fertile land for growing and infestation to $S$. chrysanthemoids weed. Growth, development and infestation of $S$. chrysanthemoids were highly correlated to cattle excreta. These excreta might be good nutrient to the weed. The study area have various noxious rangeland weeds e.g. Berberis erythroclada Ahrendt, Anaphalis contorta (D. Don) Hook.f., Potentilla lineata Trev., Euphorbia wallichii Hook. f. and Swertia pedicellata Banerji. The population density of Swertia pedicellata Banerji was 126 individual/ $\mathrm{m}^{2}$ (Limbu et al., 2012). Population density of Senecio aquaticus in grassland of Switzerland was 8-60 individual/ $\mathrm{m}^{2}$ (Suter and Luscher, 2011). Highly slope areas (more than $45^{\circ}$ inclination) were not apt to construct cattle shed and excreta would not deposit. The weed, S. chrysanthemoids, was high competitor for growing at abandoned place of cattle shed after removing cattle sheds. It dominated over other forbs and grasses. Management of this weed, control measure, was not effective. Unplanned mechanical 
Dil Kumar Limbu, Ram Prasad Khatiwada and Madan Koirala / Our Nature (2012) 10: 1-7

Table 1. Number of sample area selected according to slope of the land and use of land

\begin{tabular}{lllll}
\hline \multirow{2}{*}{ Use of the land } & Slope of the land & \multirow{2}{*}{ Total } \\
\cline { 2 - 3 } & Highly sloped (HS) & Gently sloped (GS) & \\
\hline shed-constructed area (SA) & 4 & 13 & 17 \\
not shed-constructed area (NSA) & 14 & 7 & 21 \\
\hline Total & 18 & 20 & 38 \\
\hline
\end{tabular}

Table 2. Descriptive measures and Confidence Intervals of population density

\begin{tabular}{|c|c|c|c|c|c|c|}
\hline \multirow{2}{*}{\multicolumn{2}{|c|}{ Sample Categories }} & \multirow{3}{*}{$\begin{array}{l}\begin{array}{l}\text { No. of } \\
\text { sample } \\
\text { area }\end{array} \\
17\end{array}$} & \multicolumn{3}{|c|}{ Population density } & \multirow{2}{*}{$\begin{array}{l}-95 \% \mathrm{CI} \\
\text { for mean }\end{array}$} \\
\hline & & & Range & Mean S. D. & $\begin{array}{l}\text { S. E. of } \\
\text { Mean }\end{array}$ & \\
\hline \multirow{2}{*}{ Use of the land } & shed-constructed area (SA) & & 47.00 & 44.3210 .964 & 2.659 & $38.69-49.96$ \\
\hline & not shed-constructed area (NSA) & 21 & 7.50 & 18.482 .235 & 0.488 & $17.46-19.50$ \\
\hline \multirow{2}{*}{ Slope of the land } & highly sloped (HS) & 18 & 21.50 & 21.887 .120 & 1.678 & $18.33-25.42$ \\
\hline & gently sloped (GS) & 20 & 63.75 & 37.3916 .476 & 3.684 & $29.68-45.10$ \\
\hline Total & & 38 & 63.75 & 30.0414 .977 & 2.430 & $25.12-34.96$ \\
\hline
\end{tabular}

Box plot

Use of the land

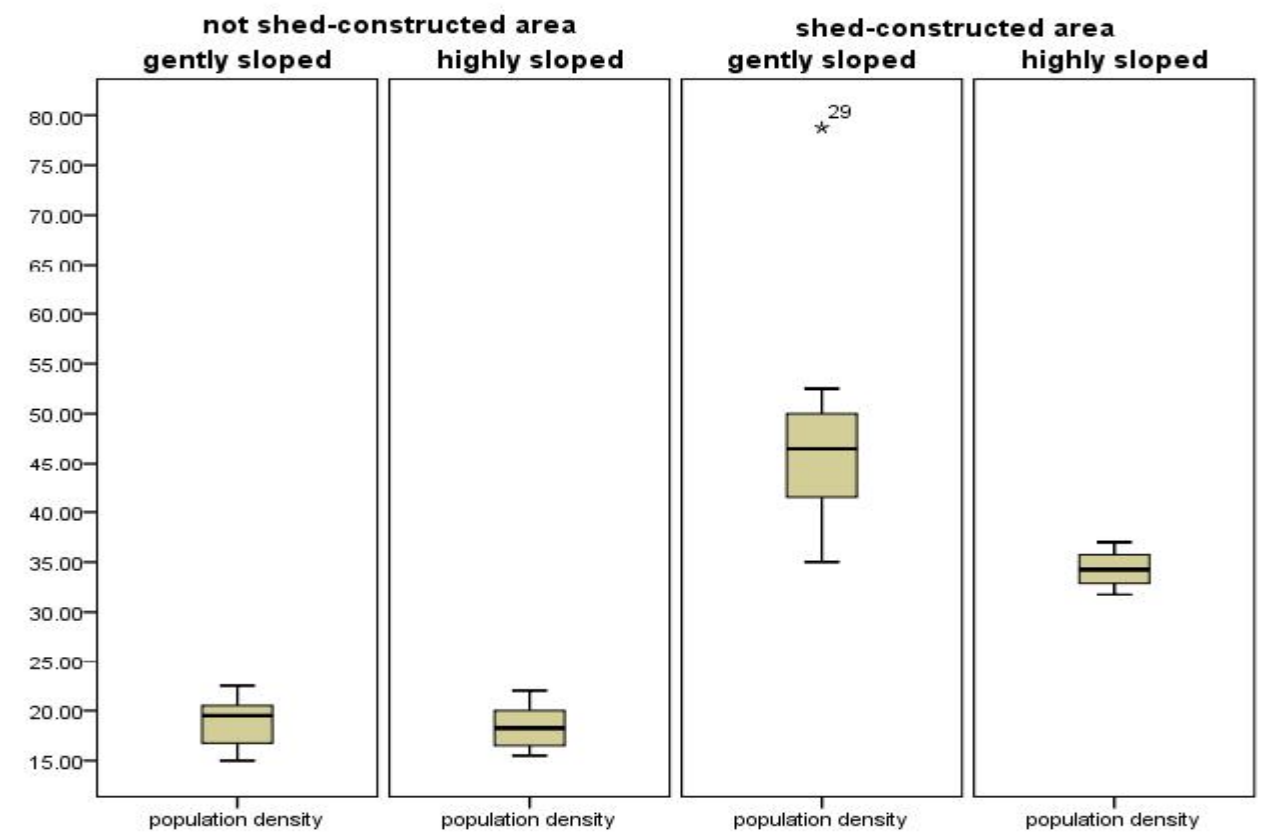

Figure 2. Distribution of population densities in different sample areas 
Dil Kumar Limbu, Ram Prasad Khatiwada and Madan Koirala / Our Nature (2012) 10: 1-7

Table 3. Descriptive measures and Confidence Intervals of population density for the cross categories

\begin{tabular}{|c|c|c|c|c|c|c|c|}
\hline \multirow{2}{*}{ Slope of the land } & \multirow{2}{*}{ Use of the land } & \multirow{2}{*}{$\begin{array}{l}\text { No. of } \\
\text { sample- } \\
\text { area }\end{array}$} & \multicolumn{3}{|c|}{ Population density } & \multirow{2}{*}{\multicolumn{2}{|c|}{$\begin{array}{l}\text { S. E. of } 95 \% \text { CI } \\
\text { Mean for mean }\end{array}$}} \\
\hline & & & Range & Mean & S. D. & & \\
\hline \multirow{3}{*}{ Gently sloped (GS) } & shed-constructed area (SA) & 13 & 43.75 & 47.40 & 10.743 & 2.980 & $40.91-53.89$ \\
\hline & not shed-constructed area (NSA) & 7 & 7.50 & 18.79 & 2.782 & 1.051 & $16.22-21.36$ \\
\hline & shed-constructed area(SA) & 4 & 5.25 & 34.31 & 2.154 & 1.077 & $29.42-39.20$ \\
\hline \multicolumn{2}{|l|}{ Highly sloped (HS) ${ }_{n}$} & 14 & 6.50 & 18.32 & 2.008 & 0.537 & $17.16-19.48$ \\
\hline
\end{tabular}

control measure was inadequate for arresting its invasion. Up-rooting weed earlier flowering season was more effective than other life form of weed because plant would not get seed produce and regenerate more.

In conclusion, S. chrysanthemoids is highly obnoxious weed, continuously infesting on Himalayan rangeland. Its distribution is not homogeneous, dense populated in left place of shed constructed area. Mechanical weed control operation just before flowering season is effective for weed control. Population density estimation of weed determines appropriate control measure on Himalayan rangeland.

\section{Acknowledgements}

The authors wish to thank informants and herdsmen of study area, Tinjure-Milke. We also thank Mr. J.B. Limbu, R. Bhattarai and P. Sherpa. The first author is grateful to the University Grants Commission, Nepal for the research fellowship.

\section{References}

Blom, C.W.P.M. 1988. The realism of models on plant demography. Acta Botanica Neerlandica 37: 421-438.

Cavers, P.B. 1985. Intractable weeds - Intraspeci ${ }^{\circledR} \mathrm{C}$ variation must be considered in formulating control measures. In Proceedings British Crop
Protection Conference Weeds, Brighton, UK. pp. 367-376.

Chancellor, R.J. 1985. Changes in the weed flora of an arable field cultivated for 20 years. Journal of Applied Ecology 22: 491-501.

Colbach, N. and P. Debaeke 1998. Integrating crop management and crop rotation effects into models of weed population dynamics: a review. Weed Science 46: 717-728.

Cousens, R. and M. Mortimer 1995. Dynamics of weed populations. Cambridge University Press, Cambridge.

DiTomaso, J.M. 2000. Invasive weeds in rangelands: species, impacts, and management. Weed Sci. 48: 255-265.

Holst, N., I.A. Rasmussen and L. Bastiaans 2007. Field weed population dynamics: a review of model approaches and applications. Weed Res. 47: 1-14.

Koirala, M. 2002. Environmental determinants of the livelihood related food production system in a mid-Himalayan landscape (Tinjure-Milke region), East Nepal. Jawaharlal Nehru University, New Delhi, India. Ph.D. Thesis.

Kropff, M.J., J. Wallinga and L.A.P. Lotz 1996. Weed population dynamics. In Proceedings Second International Weed Control Congress, (Eds. H. Brown, G.W. Cussans, M.D. Devine, S.O. Duke, C. Fernandez-Quintanilla, A. Helweg, R.E. Labrada, M. Landes, P. Kudsk and J.C. Streibig), Copenhagen, Denmark. pp. 3-14.

Liebman, M., C.L. Mohler and C.P. Staver 2001. Ecological management of agricultural weeds. Cambridge University Press, Cambridge.

Limbu, D.K., M. Koirala and Z. Shang 2012. A survey of Himalayan rangeland weeds in Tinjure-Milke-Jaljale area. Nepalese Journal of Biosciences 2: 24-30. 
Dil Kumar Limbu, Ram Prasad Khatiwada and Madan Koirala / Our Nature (2012) 10: 1-7

Masters, R. A. and R. L. Sheley 2001. Principles and practices for managing rangeland invasive plants. J. Range Manag. 54: 502-517.

Mortimer, A.M. and P.D. Putwain 1984. The prediction of weed infestations: concepts and approaches. Bulletin OEPP 14: 439-446.

Navas, M.L. 1991. Using plant population biology in weed research: a strategy to improve weed management. Weed Research 31: 171-179.

Oli, K.P. 2002. An assessment of Tinjure, Milke and Jaljale (TMJ) area of eastern Nepal. Internal Document, IUCN, Nepal.

Rajbhandari, K.R. and R. Joshi 1998. Crop weeds of Nepal. Natural History Society of Nepal, Kathmandu.

Rew, L.J., G.W. Cussans, M.A. Mugglestone and P.C.H. Miller 1996. A technique for mapping the spatial distribution of Elymus repens, with estimates of the potential reduction in herbicide usage from patch spraying. Weed Research 36: 283-292.

SPSS-20 2011. Statistical package for Statistical Sciences. IBM ${ }^{\circledR}$ SPSS ${ }^{\circledR}$ Version 20, IBM corporation, $\quad 1989$, 2011. (http//:www.ibm.spss.statistics)

Suter, M. and A. Luscher 2011. Measures for the control of Senecio aquaticus in managed grassland. Weed research 51: 601-611.

Tiwari, S., B. Adhikari, M. Siwakoti and K. Subedi 2005. An inventory and assessment of invasive alien plant species of Nepal. IUCN, Kathmandu, Nepal.

Vallentine, J.F. 1990. Grazing management Academic Press, New York.

Van Groenendael, J.M. 1988. Patchy distribution of weeds and some implications for modelling population dynamics: a short literature review. Weed Research 28: 437-441. 